\title{
Effects of human capital and fund characteristics on mutual
}

\section{fund performance in Malaysia [version 1; peer review: 2}

\section{approved with reservations]}

\author{
Venny Sin-Woon Chong (D1), Lai Ming Ming (D)2, Lee Lee Chong² \\ ${ }^{1}$ Faculty of Business, Multimedia University, Bukit Beruang, Melaka, 75450, Malaysia \\ ${ }^{2}$ Faculty of Management, Multimedia University, Cyberjaya, Selangor, 63100, Malaysia
}

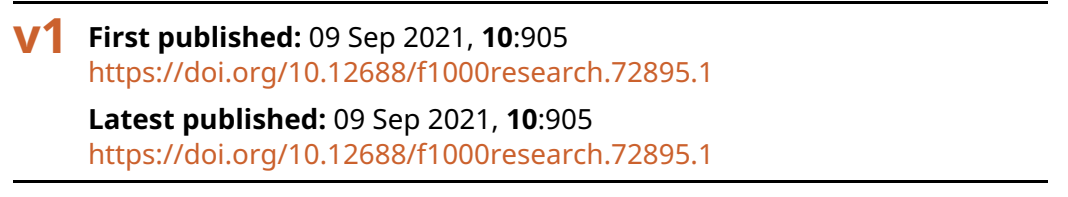

\section{Abstract}

Background: The evolution of the mutual funds industry has changed investors' perspective. Instead of just focusing on which fund performances are best, investors pay great attention to who is managing and delivering superior returns in their investment portfolios. Nonetheless, it is very scant of comprehensive studies concern with human capital managerial characteristics that link with fund performances. Hence, this study proposes the integration of fund performances, managerial characteristics, systematic risk, expense, and turnover ratio, with single and simultaneous equations based on asset pricing models.

Methods: Using a sample of Malaysian fund managers, data from fund management companies, Thomson One database, and fund master prospectus over the periods of January 2012 to December 2014, the fund performance was measured using Jensen alpha (CAPM single factor), and Fama and French three-factor model on single and simultaneous equations. The examination was further carried out by employing the ordinary least squares and three-stage least squares methods.

Results: The results suggest that for fund managers, holding a business degree was the key factor to determine the fund performance, while having Master's degree was not the primary concern. Fund performance and risk behavior varied across fund managers of different gender.

Conclusions: The expense ratio, turnover ratio, and fund objective were significantly correlated with fund performance. This study provides ultimate implications for fund management companies, when it comes to the efficient allocation of human capital. Fund management companies should focus more on the team-managed funds phenomenon, instead of on single-managed funds. Overall, this study provides significant guidance for the Malaysian Securities Commissions and fund management companies, to develop a more

\section{Open Peer Review}

Approval Status ? ?

12

version 1

$\begin{array}{cc}? & ? \\ \text { view } & \text { view }\end{array}$

09 Sep 2021

1. Yi Fang ID, Jilin University, Changchun, China

2. Fadillah Mansor (iD), University of Malaya, Kuala Lumpur, Malaysia

Any reports and responses or comments on the article can be found at the end of the article. 
competent funds market in Malaysia. Specifically, by strengthening the fund industry policies, the typical agency problems, such as too-

high managerial expenses, and excessive risk-taking can be alleviated.

Keywords

Human capital, fund manager, fund characteristics, fund

performance, expense ratio, turnover ratio, systematic risk

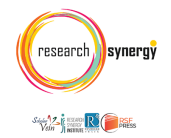

This article is included in the Research Synergy

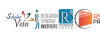

Foundation gateway.

Corresponding author: Venny Sin-Woon Chong (swchong@mmu.edu.my)

Author roles: Chong vsW: Data Curation, Formal Analysis, Investigation, Methodology, Validation, Writing - Original Draft Preparation, Writing - Review \& Editing; Ming Ming L: Conceptualization, Supervision; Chong LL: Conceptualization, Supervision

Competing interests: No competing interests were disclosed.

Grant information: The author(s) declared that no grants were involved in supporting this work.

Copyright: @ 2021 Chong VSW et al. This is an open access article distributed under the terms of the Creative Commons Attribution License, which permits unrestricted use, distribution, and reproduction in any medium, provided the original work is properly cited.

How to cite this article: Chong VSW, Ming Ming L and Chong LL. Effects of human capital and fund characteristics on mutual fund performance in Malaysia [version 1; peer review: 2 approved with reservations] F1000Research 2021, 10:905

https://doi.org/10.12688/f1000research.72895.1

First published: 09 Sep 2021, 10:905 https://doi.org/10.12688/f1000research.72895.1 


\section{Introduction}

Mutual fund is an investment vehicle for investors to yield savings and diversification. The growth of fund investments has been astounding, not only in developed countries but also in emerging markets. The unit trust industry in Malaysia has experienced phenomenal positive growth in NAV of RM536.86 billion in April 2021, and the percentage of NAV to Bursa Malaysia market capitalization showed increasing trends, from 27.36 percent in 2011 to 29.20 percent in April 2021 (Securities Commission Malaysia, 2021). Nevertheless, this growth figure was rather low compared to other advanced and mature markets. The total net assets of mutual funds managed by US investment companies in April 2021 reached more than \$25.5 trillion (USD) (Investment Company Institute, 2021), while European countries achieved $\$ 14,447.20$ billion (EUR) in March, 2021 (European Central Bank, 2011). This indicates that the unit trust industry is still in the infancy stage in Malaysia.

Nevertheless, uncertainty and reduced stability in the global financial marketplace during the COVID-19 pandemic, have given rise to tremendous challenges in the fund industry. Investors have become impatient, especially with the underperformance of funds, putting them at odds with funds managers (William, 2017). Hence, investors are now not only focused on which funds perform better than others, but on who could persistently safeguard their investment portfolios during these turbulent periods. Hence, fund managers are expected to react faster and work under pressure in this competitive market to maintain and improve their positions (PWC, 2020). The investors pay great attention to who is delivering "alpha" in their investment portfolios. However, to date, no comprehensive study has examined the relationship of fund managers' human capital characteristics with fund performance in Malaysia. Hence, this study proposes to integrate fund performances, managerial characteristics, systematic risk, expense ratio, and turnover ratio with single and simultaneous equations based on asset pricing models. This study attempts to fill this research gap. Therefore, the results are significant for the funds industry in emerging markets.

\section{Literature review}

Although there have been many empirical studies that found funds in Malaysia performed rather worse compared with mature markets (Low \& Ghazali, 2007), more recent empirical studies showed the Malaysian fund performance has outperformed the market (Lai \& Lau, 2010; Nur Adiana \& Aminah, 2019; Ruzita, Ling \& Rasidah, 2019). Previous studies (Atkinson et al., 2003; Bliss \& Potter, 2002; Chevalier \& Ellison, 1999; Golec, 1996) have focused on fund managers' managerial characteristics by looking at fund performance. Lately, the Central Bank of Malaysia has been the driving force to develop human capital in the Malaysian banking industry (Bank Negara Malaysia, 2021). The changing landscape and transformation in the financial sector could be achieved by building the right quality of human capital (The Malaysian Reserve, 2021). The concept of human capital was developed in 1954 by William Arthur Lewis. Becker (1962) has expanded this theory, stating that "people cannot be separated from their knowledge, skills, health, or values in the way they can be separated from their financial and physical assets. Education, training, and health are the most important investments in human capital".

Chevalier and Ellison (1999) highlighted that most investors believed that the mutual fund market had not yet achieved efficiency. Hence, fund managers who are actively involved with security selection and focused on movement in the market will not only add value to their investment portfolio, but will also produce superior performance (Low \& Ghazali, 2007). Golec (1996) and Chevalier and Ellison (1999) examined that those fund managers who held a Master's of Business Administration (MBA) degree showed positive to fund performance. This may be explained by the fact that the possession of an MBA degree equipped the fund managers with the skills related to investment risk management. Surprisingly, the absence of a Chartered Financial Analyst (CFA) title was not significantly relevant to the fund performance.

Golec (1996) highlighted that fund managers' experience was negatively related to fund alpha. Younger fund managers had higher stamina and higher job prospects in their careers. Chen, Gao, Zhang, and Zhu (2018) examined that fund managers with prior industry analyst backgrounds showed significant stock selection ability. There is limited research that has investigated the role of fund managers' gender on fund performance (Babalos, Caporale, \& Philippas, 2015). Sargis and Wing (2018) investigated the fund performance of female fund managers. The finding indicated that male portfolio managers did not possess superior investment skills than their female counterparts. The results showed no significant difference in terms of fund performance between male and female fund managers.

\section{Methods}

This study sampled a total of 240 domestic equity funds in Malaysia to measure the risk-adjusted performance of each fund, from January 2012 to December 2014. To avoid survivor bias, the sample excluded funds that have ceased to exist in the Malaysian fund market, and data only hold survivors' funds. The fund performance measurements were Jensen alpha on a single-factor model (CAPM) and alpha on a Fama and French (1993) (three-factor model). The FTSE KLCI 
three-month Malaysian Treasury bill was chosen as a benchmark to proxy market indexes and risk-free rate of return. To address the simultaneous interactions among fund performance, systematic risk, expenses, and turnover, it is worth noting that Golec (1996) and Switzer and Huang (2007) performed single equations and simultaneous equations. Consistent with prior studies, this study performed single equations by using OLS regression and simultaneous equations estimation by 3SLS regression. STATA version 12.1 was used to conduct the statistical assessments.

All fund manager human capital data were obtained from secondary sources which are available for public access. The fund managers' profiles, e.g., gender and education were retrieved, and hand-collected from each of the fund master prospectus and Morningstar; these data are under public access. Morningstar is a well-known Chicago-based financial services firm that provides in-depth analysis and rating system for fund performances and the fund managers investment experiences. Other human capital characteristics, e.g., investment experience and age data that are not publicly available in the Malaysian fund market, were obtained from a subscription to the Thomson One database and fund prospectus. In order to comply to the open data policy, the dataset was anonymised by attributing a number to each of the fund names; reviewers and readers may view and access the dataset without restrictions. Given that there is little and sometimes no available information on Malaysian fund managers' age, to overcome this problem, Chevalier and Ellison (1999) and Atkinson, Baird, and Frye (2003) proposed an estimation of age by assuming that each fund manager was 21 years old upon graduation from college. Nevertheless, the average age of graduation for a Bachelor's degree in Malaysia is approximately 24 . Hence, this study estimated the fund managers' age by adding 24 years to the number of years at work. Data on years of working experience were stated in the fund master prospectus. This research received approval number EA0372021 from the Research Ethic Committee of Multimedia University in Melaka, Malaysia.

Each of the fund managers' human capital characteristic indicators were measured using a dummy variable, defined in Table 1. Furthermore, this study examined six fund characteristics in terms of their relationship with the fund performance (Switzer \& Huang, 2007; Low, 2010). The fund characteristics data were sourced mainly from the respective fund master prospectus and annual reports of all fund management companies in Malaysia. To control the characteristics of the funds, the study classified the sample funds into two dimensions on the basis of the fund objective: growth fund and income fund dummy variables. The fund data are defined in Table 2.

\section{Results and discussion}

Table 3 reports descriptive statistics for fund performance, fund risks, and fund characteristics of the Malaysian funds industry. The average value shows a positive Jensen alpha of 0.0024 , which indicates that fund managers possessed the best stock selection ability. However, there was a significant gap in the return performance between the best and worst

Table 1. Fund managers' human capital characteristics definition.

\begin{tabular}{|c|c|}
\hline Variables & Measures \\
\hline Education & $\begin{array}{l}\text { Business major degree }=1 \\
\text { Non-business major degree }=0 \text {. }\end{array}$ \\
\hline Master's degree & $\begin{array}{l}\text { Master's degree holders }=1 \\
\text { Without master's degree }=0\end{array}$ \\
\hline Professional certification & $\begin{array}{l}{ }^{a} \text { CFA, }{ }^{b} \text { CFP or }{ }^{c} \text { CPA designation }=1 \\
\text { Without professional certification }=0\end{array}$ \\
\hline Gender & $\begin{array}{l}\text { Male }=1 \\
\text { Female }=0\end{array}$ \\
\hline Race & $\begin{array}{l}\text { Bumiputra }=1 \\
\text { Non-bumi }=0\end{array}$ \\
\hline Manager's age & $\begin{array}{l}\text { Young (Less than or equal to } 45 \text { years })=1 \\
\text { Senior ( } 46 \text { and above })=0\end{array}$ \\
\hline Investment experience & $\begin{array}{l}\text { Investment experience (Tenure }>20 \text { years) }=1 \\
\text { Investment experience (Tenure }<20 \text { years) }=0\end{array}$ \\
\hline Team managers & $\begin{array}{l}\text { More than one fund manager in a team }=1 \\
\text { Otherwise }=0\end{array}$ \\
\hline Team gender & $\begin{array}{l}\text { Mix gender in team }=1 \\
\text { Otherwise }=0\end{array}$ \\
\hline
\end{tabular}

${ }^{\mathrm{a}} \mathrm{CFA}=$ Chartered financial analyst.

${ }^{\mathrm{b}} \mathrm{CFP}=$ Certified financial planner

${ }^{\mathrm{C}} \mathrm{CPA}=$ Chartered financial analyst 
Table 2. Fund characteristics definition.

\begin{tabular}{|l|l|}
\hline Variables & Measures \\
\hline Turnover ratio & $\begin{array}{l}\text { [(Total acquisitions of the fund for the year + } \\
\text { total disposal for the year)/2] /average } \\
\text { net asset value for the fund for the year } \\
\text { calculated on a daily basis }\end{array}$ \\
\hline Expense ratio & $\begin{array}{l}\text { Fees and expenses incurred by the fund to } \\
\text { the average value of the fund calculated on a } \\
\text { daily basis }\end{array}$ \\
\hline Fund objective & $\begin{array}{l}\text { High Growth/Growth fund }=1 \\
\text { Income fund = } 0\end{array}$ \\
\hline Fund type & $\begin{array}{l}\text { Conventional fund }=1 \\
\text { Syariah fund = } 0\end{array}$ \\
\hline Fund size & $\begin{array}{l}\text { The logarithm of the firm's asset } \\
\text { size (in RM billion) }\end{array}$ \\
\hline Fund age & The number of years since the fund launched \\
\hline
\end{tabular}

Table 3. Descriptive statistics of fund performance, fund risks and fund characteristics from January 2012 to December 2014.

\begin{tabular}{|c|c|c|c|c|}
\hline Variable & Mean & Standard deviation & Max & Min \\
\hline \multicolumn{5}{|c|}{ Fund performance ${ }^{a}$} \\
\hline Jensen alpha & 0.0024 & 0.0122 & 0.0458 & -0.1184 \\
\hline Alpha 2 & 0.0005 & 0.0141 & 0.0750 & -0.1176 \\
\hline \multicolumn{5}{|l|}{ Fund risks ${ }^{b}$} \\
\hline Beta & 0.5936 & 0.8298 & 9.2251 & -2.4569 \\
\hline SMB & 0.2841 & 0.2872 & 0.6239 & -0.0778 \\
\hline HML & 0.5620 & 0.2773 & 0.8907 & 0.2135 \\
\hline \multicolumn{5}{|c|}{ Fund characteristics $^{c}$} \\
\hline Expense & 1.8765 & 0.5668 & 8.6300 & 0.2600 \\
\hline Turnover & 1.0175 & 1.0773 & 14.1100 & 0.0500 \\
\hline Size (\$ million) & 214.44 & 524.98 & 4214.91 & 0.00 \\
\hline Age (days) & 4064.24 & 3276.61 & 17067.00 & 152.00 \\
\hline
\end{tabular}

${ }^{a}$ Fund performance measurements: Jensen alpha (single-factor model), Alpha on Fama \& French three-factor model (Alpha 2).

${ }^{b}$ Fund Risk Measurement: Beta, firm size (SMB), book-to-market value (HML).

'Fund Characteristics: expense ratio (Expense), turnover ratio (Turnover), fund size (Size), age of the funds (Age).

fund managers. The average positive Alpha 2 of 0.0005 indicates that the funds slightly outperformed the market performance over the sampled period. The Beta of 0.5936 indicates that the mutual fund is relatively less risky than the market. The additional two risk factors, SMB with an average of 0.28 and HML was 0.56. Furthermore, the average value of the expense ratio was 1.8765 while the turnover ratio of sample funds was 1.0175 percent. The average fund had RM214.44 million in assets under management.

Table 4 reports the results among fund characteristics and human capital characteristics with the mutual fund performance (Jensen alpha) by using the CAPM single-factor index and alpha on Fama and French three-factor model on the single equation. The results showed that both fund performances were negatively related to fund expense, although only significant in Jensen alpha.

Fund age showed a positive correlation with both fund performances. This indicates that older funds generate higher returns. It is expected that older funds are more mature and established, and can keep the costs lower, which is in line with Gregory et al. (1997). On the other hand, the results revealed a significant, negative relationship between fund performances and fund managers' possession of a business major degree and Master's degree. Holding a Master's degree 
Table 4. OLS regressions between characteristics (human capital, fund characteristics) and fund performance from January 2012 to December 2014: single equation model

\begin{tabular}{|c|c|c|c|c|c|c|}
\hline & \multicolumn{3}{|c|}{ Jensen alpha (CAPM single-factor) } & \multicolumn{3}{|c|}{ Alpha 2 (Fama and French three-factor) } \\
\hline & Coef. & $\begin{array}{l}\text { Robust Std. } \\
\text { Error }\end{array}$ & $\mathbf{t}$ & Coef. & $\begin{array}{l}\text { Robust Std. } \\
\text { Error }\end{array}$ & $\mathbf{t}$ \\
\hline Expense & -0.0017 & 0.0009 & $-2.0100 * *$ & -0.0015 & 0.0011 & -1.3700 \\
\hline Turnover & -0.0005 & 0.0008 & -0.6400 & -0.0010 & 0.0009 & -1.2100 \\
\hline Size & 0.0000 & 0.0000 & 0.3600 & 0.0000 & 0.0000 & -0.8900 \\
\hline Objective & 0.0008 & 0.0011 & 0.7500 & -0.0012 & 0.0014 & -0.8600 \\
\hline Fund type & 0.0015 & 0.0011 & 1.4100 & 0.0012 & 0.0012 & 0.9600 \\
\hline Fund age & 0.0000 & 0.0000 & $-4.1900 * \star *$ & 0.0000 & 0.0000 & $-2.3700 * \star$ \\
\hline Education & -0.0000 & 0.0011 & $-0.0200 *$ & -0.0008 & 0.0014 & -0.5600 \\
\hline Master & -0.0015 & 0.0009 & $-1.7300^{*}$ & 0.0002 & 0.0010 & 0.1500 \\
\hline Certificate & 0.0005 & 0.0009 & 0.5300 & -0.0005 & 0.0011 & -0.4800 \\
\hline Experience & -0.0010 & 0.0019 & -0.5200 & -0.0008 & 0.0018 & -0.4400 \\
\hline Gender & 0.0006 & 0.0014 & 0.4500 & -0.0007 & 0.0017 & -0.4100 \\
\hline Race & -0.0012 & 0.0011 & -1.1200 & -0.0009 & 0.0013 & -0.6800 \\
\hline Manager age & 0.0023 & 0.0017 & 1.3600 & 0.0034 & 0.0017 & $2.0600 * \star *$ \\
\hline Team manager & 0.0041 & 0.0014 & $2.9600 * \star \star$ & 0.0038 & 0.0019 & $2.0300 * * *$ \\
\hline Team gender & -0.0020 & 0.0008 & $-2.4000 * \star$ & -0.0024 & 0.0011 & $-2.2700 * \star *$ \\
\hline R-square & & & 0.0980 & & & 0.0602 \\
\hline F-value & & & 4.42 & & & 2.94 \\
\hline
\end{tabular}

Dependent variable: Jensen alpha (CAPM single-factor); Alpha 2 (Fama \& French three-factor).

Notes: The asterisks ***, ** and * denote significance level at $1 \%, 5 \%$ and $10 \%$ respectively.

decreased the Jensen alpha, which indicates that fund managers with a Master's degree did not add value to their portfolio performance and their stock-picking ability. This result is consistent with Switzer and Huang (2007).

The age of managers showed a positively significant impact on both fund performances. This is consistent with Gibbons and Murphy (1992). The senior managers who are approaching retirement avoid poor performance which may hurt fund manager's reputation and reduce their job prospects in the future. The manager team showed a positive relationship with both of the fund performances. This suggests that funds managed by a team tend to benefit the mutual fund. This is consistent with Berkowitz and Qiu (2003). On the other hand, team gender showed a negative impact on fund performances. This indicates that mixed gender in a team underperformed.

Table 5 presents an integrated model of fund characteristics, human capital characteristics, and mutual fund performance, in a simultaneous equation model.

\section{Panel A: Fund performance regressions}

Both fund performances (Jensen alpha and Alpha 2) were statistically significantly and negatively related to the expense ratio in the simultaneous equation. The fund managers who charge higher expense fees might reduce the fund alpha. This result is consistent with Golec (1996), Switzer and Huang (2007). The turnover ratio showed a positively significant relationship with Jensen's alpha, which is consistent with Golec (1996). Moreover, the older funds produced better alpha.

The business major degree and Master's degree both showed statistically significant relationships with Jensen alpha. Hence, the funds managed by fund managers with business degrees tend to increase the return. Consistent with Switzer and Huang (2007), fund managers with a Master's degree slightly decreased the Jensen alpha. However, and surprisingly, a professional certification showed no significant influence on both fund performances. Fund managers with a long investment experience had a significantly negative impact on Jensen alpha. This indicates that fund managers with more than 20 years of investment experience do not perform better. 


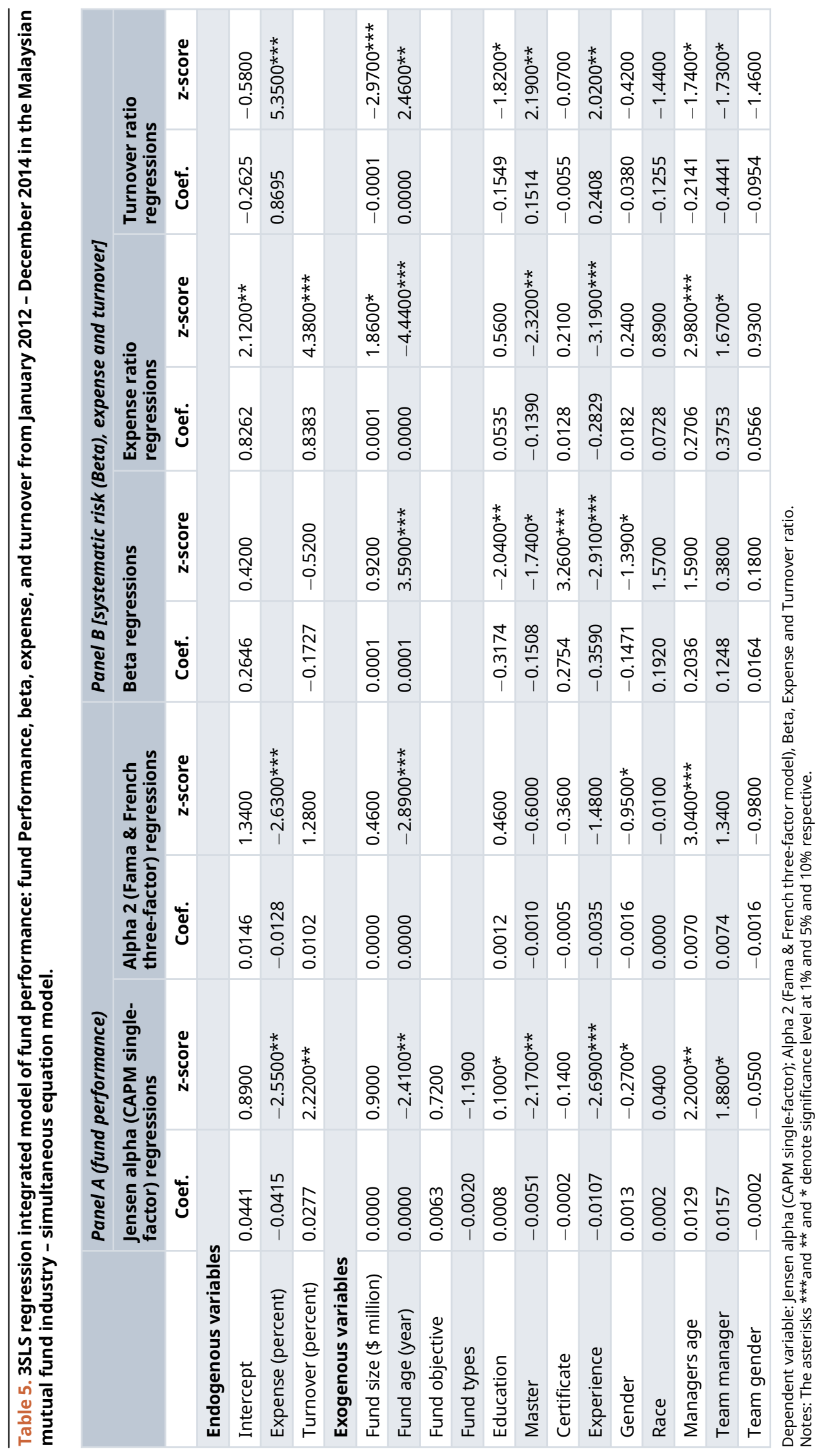


Gender appeared to have a positive impact on Jensen alpha, which indicates that male managers were likely to slightly outperform. Additionally, manager age showed a positively significant effect in both of the fund performances. This indicates that senior fund managers had a longer tenure and thus better experience, which led them to generate better fund performance. In addition, the manager age was positively correlated with the fund manager's experience tenure. On the other hand, team-managed funds showed a significant, positive relationship with Jensen alpha. This indicates that funds managed by more than one fund manager performed better than funds only managed by one.

\section{Panel B: Beta, expense and turnover regressions}

The fund age had a positive effect on systematic risk. This result is consistent with Golec (1996). This indicates that older funds are riskier than young funds. Business major and Master's degree possession showed a statistically significant, negative effect when accounting for the simultaneity. On the other hand, investment experience showed a negative significant relationship with systematic risk. In addition, female fund managers held a higher systematic risk in their fund portfolio, which was consistent with Barber and Odean (2002) and Switzer and Huang (2007). Although professional certification did not show a significant effect in fund performance, it showed a significant, positive effect on beta regression. This indicates that the fund managers who have a professional certification hold higher-risk portfolios.

With regards to the expense regression, the turnover coefficient was positively significant, which is consistent with Golec (1996) and Switzer and Huang (2007). This means that increased trading activity by fund managers is related to higher-expense funds. Fund size has a positive effect on the expense regression, while fund age showed a negative impact on expense ratio. On the other hand, fund managers' possession of a Master's degree and longer tenure of investment experience showed a negative relationship with the expense ratio. Manager age showed a positive impact on expense ratio. Senior fund managers may require higher compensation than young managers.

With regards to turnover regression, the expense ratio positively affected the turnover ratio. This result is consistent with Switzer and Huang (2007). The higher trading activity may tend to have relatively higher expense costs. The funds with larger fund sizes always showed a more active trading, while fund age had a positive impact on turnover ratio. This indicates that older funds trade more frequently. The fund managers who had business degrees showed a negative impact on portfolio turnover. While fund managers' in possession of a Master's degree tended to trade more often. Investment experience was significantly positively related to turnover ratio. The age of the fund managers and team managers showed a negative correlation with turnover ratio. Fund managers below 45 years of age traded more often than senior fund managers. It can be concluded that there is an interrelationship among fund characteristics, human capital characteristics, and fund performance.

\section{Conclusions}

A substantial emphasis is placed on how human capital roles can affect the ultimate work performance of an individual. To date, very little attention has been devoted to seeking empirical evidence for the effects of human capital managerial characteristics especially in the funds industry. Hence, this study identified that fund managers' education, gender, age, and team managers are significant characteristics in explaining fund performance. Hence, this study provides greater support for human capital theory (Becker, 1964). Although the findings showed that gender is a significant variable in explaining fund performance, the study was unable to provide clear evidence on whether female fund managers in Malaysia outperform their male counterparts. Hence, the relationship between gender and fund performance might need further investigation. To develop a more efficient and competent funds market and financial system, Malaysian regulators need to strengthen fund industry policies and practices, so that typical agency problems, such as excessive managerial expenses and risk-taking can be alleviated.

\section{Data availability \\ Underlying data \\ Figshare: Venny Chong data, https://doi.org/10.6084/m9.figshare.14870556. ${ }^{11}$}

This project contains the raw human capital, fund characteristics and fund performance data for Malaysia.

Data are available under the terms of the Creative Commons Zero "No rights reserved" data waiver (CC0 1.0 Public domain dedication). 
1. Atkinson SM, Baird SB, Frye MB: Do Female Mutual Fund Managers Manage Differently? J Financial Res. 2003; 26(1): 1-18. Publisher Full Text

2. Arif I, Jawaid T: Effect of fund managers' characteristics on mutual funds performance and fee in emerging market of Paksitan. Munich Personal RePEC Archive (MPRA). 2011: 58936.

3. Babalos V, Caporale GM, Philippas N: Gender, style diversity, and their effect on fund performance. Res Int Business Finance. 2015, 35: 57-74.

Publisher Full Text

4. Baer M, Kempf A, Ruenzi S: Team management and mutual funds. CFR Working Paper, 05-10. Cologne: University of Cologne; September 2005; 2005

5. Bank Negara Malaysia: Human Capital Development. 2021 (accessed 25th April, 2021). Reference Source

6. Barber BM, Odean T: Boys will be boys: Gender, overconfidence, and common stock investment. Quarterly J Econ. 2001; 116: 261-292.

7. Becker GS: A theoretical and empirical analysis with special reference to education. 3rd ed. The University of Chicago Press; 1994.

8. Beckmann D, Menkhoff L: Will women be women? Analyzing the gender difference among financial experts. Kyklos. 2008; 61(3): 364-384.

Publisher Full Text

9. Carhart MM: On persistence in mutual fund performance. J Finance. 1997; 52(1): 57-82.

Publisher Full Text

10. Chevalier J, Ellison G: Are some fund managers better than others? Cross-sectional patterns in behavior and performance. J Finance. 1999; 54: 875-879.

Publisher Full Text

11. Chong SW, Lai M-M, Chong LL: Venny Chong data.xlsx. figshare. Dataset. 2021

Publisher Full Text

12. Chow TK: An empirical study of mutual funds managers' Characteristics. Unpublished master's thesis. Canada: Simon Fraser University; 2007.

13. Ding B, Wermers R: Mutual fund "Stars": The performance and behavior of U.S. fund managers. Working Paper. 2004. (accessed 20 October 2011).

Reference Source

14. European Central Bank: 2021. (accessed 20 May 2021). Reference Source

15. Fama EF, French KR: Common risk factors in the returns on stocks and bonds. J Financial Economics. 1993; 33: 3-56. Publisher Full Text

16. Fang $\mathrm{Y}$, Wang $\mathrm{H}$ : Fund manager characteristics and performance. Investment Analysis J. 2015; 44(1): 102-116. Publisher Full Text

17. Federation of Investment Managers Malaysia: Industry Statistics. 2014. (accessed 10 May 2015).

Reference Source

18. Gottesman AA, Morey MR: Manager education and mutual fund performance. J Empirical Finance. 2006; 13: 145-182. Publisher Full Text

19. Gozbasi O, Citak L: An evaluation of the attributes considered by investment professionals in selecting mutual funds: The case of Turkey. Int Res J Finance Economics. 2010; 36: 180-195.

20. Han Y, Noe T, Rebello M: Horses for courses: Fund managers and organizational structures. University of Oxford; 2012 (accessed 15 March 2015). Reference Sourc

21. Investment Company Institute: Investment Company Fact Book 2016. (accessed 20 May 2018). Reference Source

22. Islamic Fund and Wealth Management Blueprint: Securities Commission Malaysia. 2017. (accessed 20 May 2018). Reference Source

23. Jensen MC: The performance of mutual funds in the period 19451964. J Finance. 1968; 23: 389-416. Publisher Full Text

24. Karagiannidis I: The effect of management team characteristics on risk-taking and style extremity of mutual fund portfolios. Review Financial Economics. 2012; 21: 153-158. Publisher Full Text
25. Lai MM, Lau SH: Evaluating mutual fund performance in an emerging Asian economy: The Malaysian experience. J Asian Economics. 2010; 21: 378-390.

Publisher Full Text

26. Li H, Zhang $X$, Zhao R: Investing in talents: manager characteristics and hedge fund performance. J Financial Quantitative. 2011; 46(1): 59-82.

Publisher Full Text

27. Low SW: Malaysian unit trust funds' performance during up and down market conditions. Managerial Finance. 2007; 33(2): 154-166.

28. Low SW, Ghazali NA: The price linkages between Malaysian unit trust funds and the stock market. Managerial Finance. 2007; 33(2): 89-101.

Publisher Full Text

29. Malaysian Industrial Development Finance Berhad: 2011. (accessed 15 January 2014). Reference Source

30. McFadden D: Chapter 6 Simultaneous Equations. 1999. (accessed 16 May 2016). Reference Source

31. Morningstar Research Report: Fund managers by gender. 2015 (accessed 5 March 2017). Reference Source

32. Morningstar.co.uk: Do you own multiple funds run by the same manager?. 2015. (accessed 15 April 2017). Reference Source

33. Niessen A, Ruenzi S: Sex matter: Gender and mutual funds. Centre for Financial Research. Working Paper. 2006. Reference Source

34. Niessen A, Ruenzi S: Sex matters: Gender and prejudice in the mutual fund industry. SSRN. Working Paper. 2013. (accessed 15 May 2015) Reference Source

35. Niessen A, Ruenzi S: Sex Matters: Gender bias in the mutual fund industry. SSRN. Working Paper. 2017. (accessed 10 June 2017). Reference Source

36. Nur Adiana AH, Aminah S: A comparative analysis of fixed income unit trust funds versus equity unit trust funds in Malaysia. Asian Acad Management J Accounting Finance. 2019; 15(2): 95-117. Publisher Full Text

37. Peterson JD, Pietranico PA, Riepe MW, et al.: Explaining aftertax mutual fund performance. Financial Analysts J. 2002; 58(1): 75-86.

38. Philpot J, Peterson CA: Manager characteristics and real estate mutual fund returns, risk and fees. Managerial Finance. 2006; 32(12): 988-996. Publisher Full Text

39. Plantier LC: Globalisation and the Global Growth of Long-Term Mutual Funds. ICI Global Research Perspective. 2014; 1(1). Reference Source

40. PWC: Covid-19 and The Mutual Fund Industry. 2021 (accessed 19 May 2021). Reference Source

41. Reilly FK, Brown KS: Investment analysis and portfolio management 7th ed. New York: Thompson South-Western, Ohio; 2003.

42. Ruzita AR, Ling PS, Rasidah MR: Performance of local versus international focus Malaysian- based mutual funds. Asian Acad Management J Accounting Finance. 2019; 15(2): $53-75$

43. Securities Commission: Statistics for fund management industry 2011. (accessed 5 May 2016). Reference Source

44. Securities Commission: 2021. (accessed 5 May 2021). Reference Source

45. Sharpe WF: Mutual fund performance.J Business. 1966; 39(1): 119-138.

46. Shukla R, Singh S: Are CFA charterholders better equity fund maangers? Financial Analysts J. 1994; 50(6): 68-74. Publisher Full Text

47. Smith A: The Wealth of Nations. 1776. (accessed 5 March 2015). Reference Source

48. Switzer LN, Huang YF: How does human capital affect the performance of small and mid-cap mutual funds? J Intellectua Capital. 2007; 8(4): 666-681. Publisher Full Text

49. Switzer LN, Mariane K: Do company visits add value for professional investors?. J Appl Finance. 2013; 23(1): 71. 


\section{Open Peer Review}

\section{Current Peer Review Status: ? ?}

\section{Version 1}

Reviewer Report 23 November 2021

https://doi.org/10.5256/f1000research.76504.r99131

(C) 2021 Mansor F. This is an open access peer review report distributed under the terms of the Creative Commons Attribution License, which permits unrestricted use, distribution, and reproduction in any medium, provided the original work is properly cited.

\section{Fadillah Mansor}

Department of Shariah and Management, University of Malaya, Kuala Lumpur, Malaysia

1. The introduction is okay.

2. The literature review is adequate, however, most of the previous studies were not recent. Also, I notice that the findings of some previous studies mentioned as support for this study's results were not explained in the literature review section, e.g. Switzer \& Huang (2007), Low (2010).

3. Methodology - the data is quite outdated, perhaps need to justify why the period was chosen. The equation of the tested models was also not presented in this study.

4. Statistical analysis - In Table 1, mentioned dummy measures, $1 ; 0$, but why results in Table 5 cannot capture and display this measurement, e.g. result of gender between male and female (as mentioned in the conclusion). Others, e.g. results of the dummy variable, fund managers' experience, or less experience. I believe that the statistical part needs rigorous analysis such as normality test and robustness test for clarity.

5. Referring to the results and discussion section, it needs further explanation about the findings, e.g. on risk, why results have shown that using SMB, the value is smaller/difference, rather than using the two other risk factors. For expense ratio and turnover ratio results, it needs to justify whether the results are supported or not supported by the previous studies.

6. I also suggest putting a note under the regression tables of the data analysis.

7. Presentation- some sentences were incomplete. eg. ..this is consistent with $x x(x x x x)$. It needs further clarification (see paragraph before Table 5 for example).

8. Conclusion - not clearly concluded effects of human capital, as well as the significance fund characteristics that influence fund performance was not highlighted in the conclusion 
section. The key findings were not clearly highlighted. Also, I cannot find Becker's (1964) theory discussed in the earlier section. Please justify.

9. References - recent previous studies are very limited. please add on relevant recent studies especially in the years 2019-2021.

Is the work clearly and accurately presented and does it cite the current literature? Partly

Is the study design appropriate and is the work technically sound? Partly

Are sufficient details of methods and analysis provided to allow replication by others? Partly

If applicable, is the statistical analysis and its interpretation appropriate? Partly

Are all the source data underlying the results available to ensure full reproducibility? Yes

Are the conclusions drawn adequately supported by the results? Partly

Competing Interests: No competing interests were disclosed.

Reviewer Expertise: Islamic finance; mutual fund; fund performance

I confirm that I have read this submission and believe that I have an appropriate level of expertise to confirm that it is of an acceptable scientific standard, however I have significant reservations, as outlined above.

Reviewer Report 07 October 2021

https://doi.org/10.5256/f1000research.76504.r93843

(C) 2021 Fang Y. This is an open access peer review report distributed under the terms of the Creative Commons Attribution License, which permits unrestricted use, distribution, and reproduction in any medium, provided the original work is properly cited.

\section{Yi Fang}

Center for Quantitative Economics, Jilin University and Business School, Jilin University, Changchun, China

The paper investigates the effects of human capital and fund characteristics on mutual fund performance in Malaysia. It discusses risk-adjusted return, risk factors, and team-managed funds. 
Therefore, it is an interesting piece of work.

\section{General conclusion}

From my point of view, the study should be revised so that it can be modified better and make further contributions. More detailed comments and suggestions are listed as follows. I am totally willing to review a revised version of this paper if the authors correct and revise the paper based on my review.

1. The paper adopts Jensen alpha and alpha on a Fama and French (1993) ${ }^{1}$ to disentangle fund performance from risk and discuss the effect of risk factors. However, the principal-agent problem of mutual funds most relates to total risk (See, for example, Jorion, 2003, FAJ) ${ }^{2}$. So the paper can provide some examinations similar to Fang and Wang $(2015, \mathrm{IAJ})^{3}$. It might find evidence about risk-taking under the framework of performance associated with total risk.

2. Team-managed fund decision is a very interesting topic. However, the paper should do more work. I think the test of fund manager effects of human capital and fund characteristics should be in a different framework. Team characteristics are more important.

3. In addition, we also can find one manager regulates several funds. The paper should also discuss the phenomenon.

\section{References}

1. Fama E, French K: Common risk factors in the returns on stocks and bonds. Journal of Financial Economics. 1993; 33 (1): 3-56 Publisher Full Text

2. Jorion P: Portfolio Optimization with Tracking-Error Constraints. Financial Analysts Journal. 2003; 59 (5): 70-82 Publisher Full Text

3. Fang $\mathrm{H}$, Wang Y: ESTIMATING DYNAMIC DISCRETE CHOICE MODELS WITH HYPERBOLIC DISCOUNTING, WITH AN APPLICATION TO MAMMOGRAPHY DECISIONS. International Economic Review. 2015; 56 (2): 565-596 Publisher Full Text

Is the work clearly and accurately presented and does it cite the current literature? Partly

Is the study design appropriate and is the work technically sound? Partly

Are sufficient details of methods and analysis provided to allow replication by others? Partly

If applicable, is the statistical analysis and its interpretation appropriate? Partly

Are all the source data underlying the results available to ensure full reproducibility? Yes 
Are the conclusions drawn adequately supported by the results?

Yes

Competing Interests: No competing interests were disclosed.

Reviewer Expertise: Asset pricing, Financial market

I confirm that I have read this submission and believe that I have an appropriate level of expertise to confirm that it is of an acceptable scientific standard, however I have significant reservations, as outlined above.

The benefits of publishing with F1000Research:

- Your article is published within days, with no editorial bias

- You can publish traditional articles, null/negative results, case reports, data notes and more

- The peer review process is transparent and collaborative

- Your article is indexed in PubMed after passing peer review

- Dedicated customer support at every stage

For pre-submission enquiries, contact research@f1000.com

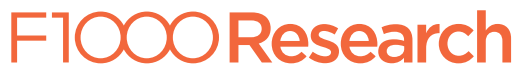

